JURNAL KETAHANAN NASIONAL

P-ISSN: 0853-9340, e-ISSN: 2527-9688

Online sejak 28 Desember 2015 di: http://jurnal.ugm.ac.id/JKN

\title{
DINAMIKA AKTUALISASI DIRI PEMUDA RANTAU DAN IMPLIKASINYA TERHADAP KETAHANAN PRIBADI (Studi Pada Mahasiswa Rantau Asal Sumatra Barat Di Asrama Putri Bundo Kanduang Daerah Istimewa Yogyakarta)
}

\author{
Irwan \\ Fresh Graduate Program Studi Ketahanan Nasional \\ irwanhamdi@ymail.com \\ Muhamad Supraja \\ Fakultas Fisipol Universitas Gadjah Mada \\ Praja3@ugm.ac.id \\ Ahmad Zubaidi \\ Fakultas Filsafat Universitas Gadjah Mada \\ azubaidyugm@gmail.com
}

\begin{abstract}
This research examined the dynamics of self-development college student migrant and its implication towards personal resilience. Particularly this research aimed to knew about the process of self-development including many factors that supported college students from Minangkabau who continued study in Yogyakarta and stayed at Bundo Kanduang Dormitory. Then, the kind of dynamics self-development would implicate of personal reselience.

Qualitative approaches had been used which emphasized on phenomena and social relations context. So there were two kinds of data resources in this paper: primary and secondary data. The primary data was collected based on in-depth interviews with research participants and deeper observation in the field. Meanwhile, secondary data relied thoroughly on published data and academic journals or papers and also documentation. Due to analyze data were used Self-Development Theory that beginning with fullfilled basic of needs.

This study indicated that college students had fullfilled their basic of needs as long as they studied in Yogyakarta. So that, the self-development process were being well. Although some obstacles occured in small scale. The form of self-development which showed traditional art, established or joint activities, cultural mixing, etc. The process of self-development sustainly had implicated to personal resilience of student. These implications were explained through some values of personal resilience.
\end{abstract}

Keywords: Self-Actualization, The Youth, Personal Resilience

\begin{abstract}
ABSTRAK
Penelitian ini menganalisis dinamika aktualisasi diri mahasiswa yang tinggal di perantauan dan implikasinya terhadap ketahanan pribadi. Secara spesifik penelitian ini bertujuan untuk mengetahui bagaimana proses pengembangan diri mahasiswa beserta faktor-faktor yang dapat mendukung dan menjadi kendala bagi mahasiswa asal Sumatera Barat/Minangkabau yang sedang melanjutkan studi di beberapa perguruan tinggi di Yogyakarta dan
\end{abstract}


tinggal di Asrama Putri Bundo Kanduang. Kemudian dari proses aktualisasi diri tersebut akan berimplikasi terhadap ketahanan pribadi mahasiswa.

Penelitian ini menggunakan metode kualitatif yang diolah berdasarkan pada pengamatan terhadap fenomena dan gejala sosial. Oleh karena itu sumber data penelitian ini dibagi atas sumber data primer dan sumber data sekunder. Sumber data primer terdiri atas wawancara mendalam terhadap informan dan observasi/pengamatan langsung di lapangan. Sementara sumber data sekunder berasal dari studi literatur dan dokumentasi. Dalam menganalisis data, penelitian ini menggunakan teori aktualisasi diri yang didahului dengan pemenuhan kebutuhan dasar dalam hidup di rantau.

Hasil penelitian ini menunjukkan para mahasiswa telah mampu memenuhi kebutuhan dasar kehidupan saat menimba ilmu di Yogyakarta. Sehingga proses aktualisasi diri berjalan dengan baik. Meskipun demikian terdapat beberapa faktor yang menghambat proses aktualisasi diri tersebut meski dalam skala yang sangat kecil. Bentuk aktualisasi diri mereka misalnya pelestarian kesenian daerah, membuat kegiatan bersama, pembauran kebudayaan, dan lain- lain. Proses aktualisasi diri yang terus menerus dikembangkan oleh mahasiswa selama menjalani proses pendidikan telah berimplikasi terhadap ketahanan pribadi. Implikasi terhadap ketahanan pribadi mahasiswa dijelaskan dalam bentuk nilai-nilai ketahanan pribadi.

\section{Kata Kunci: Aktualisasi Diri, Pemuda, Ketahanan Pribadi}

\section{PENGANTAR}

Suku bangsa Minangkabau atau Minang merupakan salah satu etnis besar di Indonesia yang secara administratif berada dalam wilayah Propinsi Sumatera Barat dan sebagian kecil wilayah di sekitarnya. Salah satu ciri yang melekat pada orang Minang adalah tradisi merantau. Winstedt (1960) dalam Kamus Bahasa Melayu menyatakan bahwa rantau merupakan 'kata benda yang berarti dataran rendah atau daerah aliran sungai yang berada di wilayah pesisir dan di luar dari daerah inti Minangkabau’ yakni Luhak Agam, 50 kota, dan Luhak Tanah Datar. Seiring perkembangan zaman kategori merantau semakin meluas sehingga makna rantau menjadi luas pula dan tidak terbatas pada daerah-daerah inti tersebut. Banyak alasan orang Minang merantau, salah satunya untuk melanjutkan pendidikan yang umumnya dilakukan oleh pemuda. Salah satu daerah tujuan merantau untuk tujuan pendidikan adalah Yogyakarta. Eksistensi pemuda Minangkabau di Yogyakarta dapat dilihat dari beberapa komunitas bercorak kedaerahan seperti IKPMD Sumbar, Forkommi UGM, Asrama Putra Merapi-Singgalang dan Asrama Putri Bundo Kanduang.
Masa studi yang dijalani mengharuskan pemuda untuk berada di 'tanah rantau' demi menyelesaikan studi dalam kurun waktu tertentu sehingga dalam jangka waktu tersebut pemuda berada jauh dari orang tua dan dihadapkan pada lingkungan sosial yang baru dan cenderung heterogen. Oleh karena peneliti mengamati bahwa terdapat dinamika perilaku pemuda saat berada di kampung halaman dengan di 'tanah rantau' salah satunya dalam aspek pengembangan atau aktualisasi diri. Pada gilirannya proses aktualisasi diri akan berimplikasi terhadap ketahanan pribadi pemuda. Jika pemuda mampu mengaktualisasikan diri melalui perilaku dan kepribadian sehari-hari maka hal itu akan menunjang penguatan ketahanan pribadi pemuda. Begitupun sebaliknya, oleh karena itu kajian mengenai aktualisasi diri pemuda sangat substansial dilakukan demi melihat kondisi ketahanan pribadinya. Ketahanan pribadi merupakan landasan utama untuk mewujudkan ketahanan nasional yang kuat dan tangguh.

Berdasarkan latar belakang diatas maka penelitian ini dilakukan dengan maksud untuk mengetahui dinamika aktualisasi diri pemuda 
rantau di Asrama Putri Bundo Kanduang Daerah Istimewa Yogyakarta dan implikasinya terhadap ketahanan pribadi pemuda tersebut. Penelitian ini utama sekali menggunakan 4 konsep kebutuhan dasar dari Abraham Maslow yaitu kebutuhan fisiologis (fisiologic needs), kebutuhan akan rasa aman (security needs), kebutuhan akan memiliki dan cinta (love needs), kebutuhan akan penghargaan (esteem needs). Kemudian terdapat 3 kebutuhan lain yang lahir setelah teori ini mendapat kritikan dan direvisi oleh para ahli yaitu kebutuhan untuk tahu dan memahami (the desire to know and to understand), kebutuhan estetika (aesthetic needs), dan kebutuhan spiritual (spiritual needs).

Setiap kebutuhan di atas dianalisis terhadap perilaku pemuda yang merupakan objek utama dalam penelitian ini. Terkait dengan terminologi pemuda sering diidentikkan dengan generasi muda atau kaum muda karena sejatinya belum ada definisi yang pasti mengenai konsep ini. Definisi pemuda menurut WHO yaitu seseorang yang berusia antara 10-24 tahun. Sementara menurut UU nomor 40 Tahun 2009 Tentang Kepemudaan dijelaskan bahwa pemuda merupakan warga negara yang berusia 16-30 tahun. Mahasiswa asrama yang menjadi obyek penelitian di sini sudah memenuhi kriteria sebagai pemuda sesuai dengan definisi di atas. Setelah analisis terhadap proses aktualisasi diri pemuda maka pada gilirannya dilakukan penelitian terhadap ketahanan pribadi pemuda sebagai implikasi dari proses aktualisasi diri. Konsepsi ketahanan pribadi begitu penting karena menjadi langkah awal dalam mewujudkan ketahanan nasional yang kuat dan tangguh. Konsepsi ketahanan nasional yang berisi ketangguhan dan keuletan bangsa memiliki makna bahwa untuk membangun ketangguhan dan keuletan tersebut dibutuhkan pribadi yang berperan sebagai subyeknya. Soedarsono (1997:51) mendeskripsikan ciri-ciri pemuda yang memiliki ketahanan pribadi yaitu memiliki rasa percaya diri dan berpegang pada prinsip, bebas dari rasa ketergantungan tetapi mendambakan kebersamaan, memiliki jiwa dinamis, kreatif dan pantang menyerah, serta mendahulukan kepentingan umum daripada kepentingan pribadi.

Penelitian ini menggunakan metode kualitatif yang diolah berdasarkan pada pengamatan terhadap fenomena dan gejala sosial. Bogdan dan taylor dalam Kaelan (2012:36) menyatakan bahwa penelitian kualitatif merupakan prosedur penelitian yang menghasilkan data deskriptif berupa kata-kata lisan, catatan-catatan yang berhubungan dengan makna, nilai serta pengertian dari orang-orang atau perilaku yang dapat diamati. Penelitian ini mengambil lokasi di Asrama Putri Bundo Kanduang yang beralamat di Jalan Bintaran no 7, Mergangsan, Wirogunan, Daerah Istimewa Yogyakarta. Pengumpulan data penelitian dibagi atas kelompok data primer dan sekunder. Data Primer menggunakan teknik triangulasi yaitu menggabungkan beberapa teknik pengumpulan data yakni teknik wawancara mendalam (in-depth interview) dan observasi. Data diambil dari warga asrama, alumni, warga sekitar serta pemuka adat Minangkabau yang ada di Yogyakarta. Melalui teknik observasi peneliti mengamati langsung terhadap subjek dan objek dalam penelitian. Subyek penelitian yaitu warga asrama dan objeknya yakni objek fisik berupa bangunan asrama dan lingkungan asrama serta objek non fisik berupa programprogram kegiatan yang diagendakan dan dilaksanakan oleh warga asrama. Kelompok 
data sekunder berasal dari studi kepustakaan, dokumentasi dan informasi-informasi dari media cetak dan elektronik. Studi kepustakaan berfungsi untuk mendefinisikan beberapa konsep yang terkait dengan penelitian.

Terkait dengan proses analisis data, Bogdan dalam Sugiyono (2013:224) menyatakan bahwa analisis data merupakan proses mencari dan menyusun data yang diperoleh dari hasil wawancara, catatan lapangan, dan bahan-bahan lain secara sistematis, sehingga mudah dipahami dan temuannya dapat diinformasikan kepada orang lain. Analisis data dalam penelitian ini menggunakan model Miles and Huberman yang menjelaskan bahwa aktivitas ini terdiri dari reduksi data, penyajian data dan selanjutnya dapat ditarik kesimpulan data secara keseluruhan.

\section{PEMBAHASAN}

Seperti yang sudah dikemukakan diatas bahwa dinamika proses aktualisasi diri pemuda rantau di Asrama Putri Bundo Kanduang dapat dianalisis dalam upaya pemenuhan kebutuhan dasar sesuai dengan konsep Abraham Maslow.

Pertama, kebutuhan fisiologis merupakan kebutuhan paling mendasar bagi setiap orang karena berkaitan dengan kelangsungan hidup dan upaya mempertahankan kehidupan secara fisik. Warga asrama memenuhi kebutuhan sehari-hari dengan cara mendapatkan kiriman uang dari orang tua atau sanak saudara secara berkala dan biasanya setiap awal bulan. Besarannya bervariasi tergantung pada kondisi ekonomi keluarga para mahasiswa. Dari beberapa informan yang peneliti wawancara, untuk besaran biaya hidup umumnya berada dalam kisaran $800.000-1.500 .000$ per bulan.
Kebutuhan fisiologis lainnya berkaitan dengan kebutuhan istirahat (tidur) dan tempat berteduh otomatis sudah terpenuhi karena para mahasiswa setidaknya tinggal di asrama dalam waktu 1 tahun. Dari informasi yang peneliti dapatkan maka dapat dinyatakan bahwa kebutuhan paling mendasar ini dapat terpenuhi dengan baik.

Kedua, kebutuhan akan rasa aman. Rasa aman yang dimaksud disini adalah perasaan tenang tanpa ada kekhawatiran terhadap potensi gangguan dari segi apapun. Kehidupan yang aman dan nyaman otomatis dibutuhkan oleh setiap manusia tidak terkecuali bagi warga asrama yang jauh dari orang tua. Kebutuhan akan rasa aman telah dibangun dan dipenuhi oleh mahasiswa warga asrama. Rasa aman dari gangguan yang berbentuk tindakan kriminal misalnya diperoleh dengan membangun kepercayaan satu sama lain dan menghilangkan rasa curiga terhadap siapapun yang tinggal di asrama. Kemudian dalam kawasan Bintaran Tengah, rasa aman dibutuhkan agar bebas dari tindakan kejahatan yang rawan terjadi dikawasan perumahan misalnya, pencurian, kemalingan, dan tindakan kriminal lainnya. Kebutuhan akan rasa aman dibangun melalui koordinasi dengan asrama setempat melalui forum Ikatan Keluarga Mahasiswa Bintaran (IKMB). Forum IKMB beranggotakan para mahasiswa dari asrama sejenis yang berada di kawasan Bintaran. Forum ini bertanggung jawab untuk menjaga dan menciptakan rasa aman dan nyaman bagi seluruh warga disekitar Bintaran Tengah.

Bentuk kegiatan yang mencerminkan upaya penciptaan rasa aman tersebut yaitu pembagian jadwal ronda setiap malam, koordinasi dengan kepolisian setempat serta mengajak seluruh masyarakat kawasan Bintaran 
Tengah untuk senantiasa meningkatkan kewaspadaan diri, keluarga, harta benda serta rumah masing-masing. Warga Bintaran sangat mengapresiasi adanya forum IKMB ini dan berharap forum ini tetap dibangun terus menerus dan berkelanjutan oleh mahasiswa di kawasan Bintaran tersebut. Kegiatan di atas membuktikan bahwa warga asrama telah mampu memenuhi kebutuhan akan rasa aman sehingga dalam kegiatan sehari-hari terutama dalam pengembangan diri warga asrama dapat dilaksanakan dengan perasaan tenang, nyaman dan bebas dari rasa khawatir.

Ketiga, kebutuhan akan memiliki dan cinta. Kasih sayang dan cinta dalam hubungan sesama manusia mutlak dibutuhkan karena manusia merupakan makhluk sosial. Warga asrama membangun rasa kasih sayang diantara mereka dalam bentuk saling mengingatkan dan saling peduli satu sama lain. Dalam bergaul di dalam lingkungan asrama mereka berusaha menghilangkan perbedaan-perbedaan seperti umur dan asal daerah atau perguruan tinggi sehingga kasih sayang dan cinta dapat dibangun tanpa ada perasaan segan. Kondisi yang berbeda ketika melihat bagaimana hubungan anggota asrama dengan masyarakat sekitar Bintaran Tengah ternyata sangat minim bahkan kurang sosialisasi. Hal ini diakui seluruh informan bahwa mereka selama ini tidak terlalu dekat dan jarang membaur dengan masyarakat sekitar komplek asrama. Warga asrama jarang berinteraksi dan membangun hubungan dengan masyarakat di sekitar asrama. Interaksi sosial tersebut hanya terjalin ketika ada suatu keperluan atau ada undangan menghadiri kegiatan. Dalam kehidupan sehari-hari para anggota asrama lebih banyak menghabiskan waktunya di kampus dan di lingkungan asrama saja.
Berdasarkan pernyataan warga asrama dan hasil kroscek terhadap pihak luar asrama yang telah peneliti dapatkan, maka peneliti menilai bahwa sebagian kebutuhan akan rasa memiliki dan rasa cinta sudah terpenuhi bagi mahasiswa warga asrama. Namun sebagian lainnya tidak dapat terpenuhi dengan baik dalam hubungannya dengan masyarakat umum sekitar asrama sehingga hal ini mengurangi nilai-nilai pengembangan diri mahasiswa. Warga asrama dituntut meningkatkan interaksi dan sosialisasi dengan masyarakat sekitar komplek asrama agar pengembangan diri mereka lebih optimal. Pengembangan diri dalam bentuk interaksi tidak hanya dalam ranah yang homogen tetapi yang terpenting adalah bagaimana menempatkan diri dalam lingkungan yang majemuk/heterogen.

Keempat, kebutuhan akan penghargaan. Kebutuhan akan penghargaan ini bersumber dari diri sendiri serta orang lain. Terkait dengan penghargaan dari diri sendiri, informan merasa bahwa penghargaan jenis ini masih belum maksimal. Ini dinyatakan dalam bentuk kurangnya kepercayaan diri akan kompetensi dalam mencapai sesuatu. Sebaliknya terhadap penghargaan yang berasal dari orang lain para mahasiswa juga tidak membutuhkannya setidaknya untuk saat sekarang ini. Para mahasiswa belum memerlukan dan tidak terlalu hirau dengan bentuk penghargaan dari orang lain karena kehidupan sehari-hari yang hanya diisi dengan belajar dan bersosialisasi dengan teman sebaya atau teman dikampus. Bisa dikatakan para mahasiswa cenderung cuek dengan penghargaan yang bersifat eksternal ini.

Dari pengamatan peneliti juga menilai bahwa warga asrama cenderung pemalu dan tidak ada yang berani tampil misalnya ketika mendapatkan suatu penghargaan. Ini peneliti 
amati sendiri saat asrama ini mendapat penghargaan sebagai penampil terbaik (best performer) di acara festival kebudayaan Desember 2015 silam dimana tidak ada dari anggota asrama yang berani maju untuk menerima penghargaan. Kondisi ini sangat menggelikan karena penghargaan atas diri sendiri sejatinya penting untuk meningkatkan semangat diri. Seperti yang dikemukakan Alfred Adler dalam Goble (1987) bahwa "seseorang yang memiliki cukup harga diri akan lebih percaya diri dan mampu sehingga akan lebih produktif. Sebaliknya jika harga dirinya kurang maka ia akan selalu diliputi rasa rendah diri serta rasa tidak berdaya, yang selanjutnya dapat menimbulkan rasa putus asa serta tingkah laku neurotik”.

Kelima, kebutuhan untuk tahu dan memahami. Kebutuhan ingin tahu atau rasa ingin tahu memang bukan bagian dari kebutuhan dasar manusia namun ini merupakan dorongan naluriah manusia untuk mencari tahu segala hal yang diamati atau berada di sekitarnya yang pada gilirannya akan mendapat pemahaman terhadap suatu hal tersebut. Dari pengamatan peneliti, warga asrama memiliki rasa ingin tahu yang cukup besar dalam setiap realitas yang diamatinya. Keputusan untuk merantau dan melanjutkan pendidikan tentu juga didasarkan oleh rasa ingin tahu yang beragam. Contohnya saja ingin tahu akan pendidikan lanjutan, ingin tahu mengenai suasana di Yogyakarta, ingin tahu kondisi hidup ketika jauh dari orang tua, dan sebagainya. Dalam konteks penelitian ini, hasrat ingin tahu dan memahami merupakan salah satu dorongan positif dalam proses aktualisasi diri.

Rasa ingin tahu akan dunia pendidikan memutuskan mereka untuk melanjutkan pendidikan demi memuaskan rasa ingin tahu tersebut. Kemudian di lingkungan asrama rasa ingin tahu tercermin dari perilaku seharihari. Rasa ingin tahu dan memahami kondisi warga lainnya melahirkan sikap empati dan simpati. Sikap ini diwujudkan dalam bentuk membangun kepedulian dan saling membantu satu sama lain. Pada gilirannya sikap positif ini dapat membangun suasana keakraban sesama warga. Rasa ingin tahu terhadap kebudayaan daerah asal diwujudkan dengan mempelajari seni tari daerah secara terus menerus. Dengan belajar kesenian tari, warga asrama memahami gerakan demi gerakan tari, makna filosofis gerakan tari serta nilai-nilai yang terkandung di dalamnya. Rasa ingin tahu dan memahami akan selalu bersinggungan dengan setiap perilaku karena jika tidak memiliki hasrat keingintahuan maka proses aktualisasi diri tidak akan berjalan optimal.

Keenam, kebutuhan estetika. Bagi sebagian orang, kebutuhan akan keindahan terkadang diabaikan namun bagi sebagian lainnya kebutuhan ini menjadi sangat penting dan ditempatkan sebagai bagian dari proses aktualisasi diri karena merupakan cerminan diri sendiri. Sebagai kaum hawa, warga asrama sangat memerhatikan seni estetika dalam perilaku mereka sehari-hari. Mereka menempatkan keindahan sebagai bagian terpenting dan percaya bahwa hal itu merupakan cerminan diri sendiri sehingga keindahan menjadi kebutuhan dalam rangka aktualisasi diri. Dari pengamatan peneliti terhadap lingkungan asrama, warga asrama menata setiap ruangan dengan baik, baik ruangan kamar pribadi maupun ruangan bersama/umum, terutama yang berfungsi sebagai ruang pertemuan dengan pihak luar. Kemampuan mengatur lingkungan dengan 
apik merupakan salah satu bentuk nilai estetika yang diterapkan warga asrama.

Dalam hal penampilan sehari-hari warga asrama juga sangat concern dengan keindahan diri yang tercermin dari keselarasan cara berpakaian. Sebagai umat muslim, warga asrama menampilkan busana yang mencerminkan seorang muslimah yakni menutup aurat selama berinteraksi dengan masyarakat luar. Sementara dalam lingkungan asrama sendiri, terdapat peraturan yang khusus mengatur cara berpakaian warga asrama. Diantaranya harus menggunakan baju yang berlengan dan celana atau rok yang panjangnya harus di bawah paha.

Ketujuh, kebutuhan spiritual. Kebutuhan spiritual merupakan inti dan tujuan utama yang ingin dicapai oleh manusia dalam hidupnya. Zohar (2000) menyatakan bahwa "kita menggunakan kecerdasan spiritual untuk mencapai perkembangan diri yang lebih utuh karena kita memiliki potensi untuk itu kita dapat menggunakan kecerdasan spiritual untuk berhadapan dengan masalah baik dan jahat, hidup dan mati, dan asal usul sejati dari penderitaan dan keputusasaan manusia.” Kutipan ini membuktikan bahwa persoalan kebutuhan spiritual akan berhubungan dengan semua dimensi kehidupan.

Agama merupakan salah satu cara pengungkapan akan kebutuhan spiritual namun itu tidak mutlak. Hal ini karena terdapat perbedaan konsep antara agama dengan spiritual dari segi sumbernya. Agama menurut Zohar (2000:8): “merupakan seperangkat aturan yang dibebankan secara eksternal, bersiat top-down diwarisi melalui pendeta/nabi/ kitab suci dan ditanamkan melalui keluarga atau tradisi". Sementara spiritual merupakan kemampuan internal yang dibawa oleh otak dan jiwa manusia dimana sumber terdalamnya adalah alam semesta. Perbedaan konsep ini tidak berarti antara agama dan spiritual jadi terpisahkan secara eksplisit. Semua tergantung pada individu yang memiliki jiwa itu sendiri bagaimana ia menempatkan agama dan kebutuhan spiritual dalam jiwanya. Dalam penelitian ini peneliti menempatkan agama sebagai posisi sentral dalam pemenuhan kebutuhan spiritual warga asrama karena selain secara eksplisit dapat diamati, dalam pandangan Islam setiap perilaku positif dapat bernilai ibadah artinya dimaknai sebagai upaya mendekatkan diri kepada Sang Pencipta Allah SWT. Pada titik ini kebutuhan spiritual telah terpenuhi. Kebutuhan spiritual bagi warga asrama diwujudkan sebagai keyakinan untuk memenuhi kewajiban sebagai penganut agama Islam karena Etnis Minangkabau berlandaskan pada ajaran Islam sehingga otomatis masyarakat asli Minangkabau “harus” beragama Islam seperti falsafah Minangkabau, Adat Basandi Syarak, Syarak Basandi Kitabullah. Motivasi naluriah warga asrama dalam setiap perilaku adalah nilai-nilai ajaran Islam. Proses demi proses pengembangan diri yang dilakukan pada gilirannya dimaknai sebagai ibadah dalam rangka mendekatkan diri kepada Allah SWT.

Terkait implementasinya, dalam hadits Nabi Muhammad SAW dijelaskan sebagai berikut: "Sesungguhnya yang membedakan seseorang (muslim) dengan yang musyrik dan kafir adalah meninggalkan salat”(HR Muslim). Berdasarkan uraian hadits diatas, secara eksplisit pemenuhan kebutuhan spiritual bagi seorang muslim yang utama sekali dapat dilihat dari ibadah salatnya. Salat merupakan sebuah proses interaksi manusia dengan Penciptanya sehingga salat 
menjadi unsur utama pemenuhan kebutuhan spiritual. Orang yang telah melaksanakan salat biasanya jiwanya tenang. Pada titik ini manusia memperoleh makna dan nilai dari setiap perilaku. Peneliti tidak dapat mengamati langsung pelaksanaan kewajiban salat ini namun dari penuturan warga asrama tidak pernah meninggalkan salat 5 waktu kecuali dengan alasan tertentu yang dibenarkan menurut agama.

Selain ibadah yang bersifat pribadi di atas, Asrama Putri Bundo Kanduang juga memiliki bagian yang khusus untuk mengkoordinir kewajiban beribadah sekaligus memenuhi kebutuhan spiritual warganya yaitu seksi rohani. Seksi ini memiliki kegiatan-kegiatan misalnya salat berjamaah, mengadakan pengajian terutama saat peringatan hari besar Islam, dan bakti sosial ke panti asuhan. Salat berjamaah merupakan ibadah salat yang dilakukan secara berkelompok dengan satu orang pemimpin/imam. Ibadah ini selain menambah pahala juga dapat dimaknai sebagai upaya membangun persatuan diantara umat Islam. Pengajian ilmu agama Islam merupakan salah satu upaya membangun ketenangan bathin. Bahkan dalam istilah lain pengajian berarti siraman rohani, mengisi rohani/spiritual dengan nilai-nilai Ketuhanan. Kemudian dengan kegiatan bakti sosial merupakan upaya membangun sikap dermawan, tolong menolong sesama umat muslim. Banyak makna yang terkandung dari kegiatan ini, dari segi keyakinan sedekah akan menambah pahala dan melancarkan rezeki. Sementara dari sisi spiritual orang akan merasa tenang dan terpuaskan jiwanya jika sudah berbagi dengan orang lain.

Berdasarkan data yang didapatkan dari informan serta pengamatan peneliti di lapangan, maka dapat dideskripsikan beberapa kegiatan asrama yang mencerminkan proses aktualisasi diri warga, yaitu (1). Partisipasi aktif warga asrama dalam kegiatan kepanitiaan baik di lingkungan asrama maupun di kampus masing-masing. (2). Pelestarian seni budaya Minangkabau dalam bentu tari dan musik. Setiap warga asrama wajib menguasai beberapa tarian tradisional daerah Sumatera Barat. Untuk mewujudkan hal itu maka selalu diadakan latihan rutin di lingkungan internal asrama. (3). Partisipasi aktif warga asrama di kepengurusan organisasi mahasiswa di kampus masing-masing. (4). Partisipasi aktif dalam gelaran rutin kebudayaan nusantara yang diadakan Dinas Kebudayaan Yogyakarta. (5). Sering mengikuti kompetisi tari serta tampil di berbagai kegiatan di dalam dan luar kampus. (6). Penerbitan majalah Kaba Bundo sebagai wadah untuk mengembangkan ide dan pemikiran dalam bentuk tulisan. Majalah ini terbit 1 kali dalam 3 bulan yang memuat informasi tentang kegiatan-kegiatan yang dilakukan asrama, buah tulisan warga asrama serta pengetahuan tentang budaya Minangkabau. (7). Kegiatan rutin harian, mingguan serta bulanan warga asrama. (8). Partisipasi aktif anggota dalam forum rapat bulanan dan musyawarah tahunan asrama.

Dalam prakteknya, peneliti menemukan beberapa faktor yang menjadi pendukung serta menjadi kendala dalam pengembangan diri warga asrama. Beberapa faktor yang menjadi pendukung aktualisasi diri warga asrama terbagi atas faktor internal dan eksternal. Faktor internal, yaitu (1). Karakter yang kuat dan masih melekat sebagai gadih minang yang telah mendapat didikan sejak kecil. (2). Didikan budaya merantau dengan segala nilai-nilai filosofisnya memberi andil positif 
bagi pengembangan diri warga asrama di tanah rantau. (3). Program kegiatan asrama yang cukup banyak disertai dengan hukumanhukuman jika melanggar peraturan tersebut.

Sementara faktor pendukung yang berasal dari luar yaitu (1). Eksistensi Yogyakarta sebagai kota pelajar dan kota budaya dimana salah satu dampak positifnya adalah memberi ruang bagi kreatifitas bagi pengembangan seni dan budaya nusantara salah satunya budaya Minangkabau. (2). Masih dengan berdasar pada faktor di atas, beberapa kampus besar di Yogyakarta umumnya mereka juga memiliki unit kesenian daerah. Kondisi ini telah memacu semangat kompetisi dan berusaha menjadi yang terbaik khususnya dalam pertunjukkan seni. (3). Kepercayaan Pemprov DIY terhadap Asrama Putri Bundo Kanduang untuk tampil disetiap pertunjukkan dibandingkan dengan kelompok organisasi Minang lainnya di Yogyakarta semakin menambah semangat dan kepercayaan diri para anggota asrama. (4). Kepercayaan masyarakat Minang yang menempatkan Asrama Putri Bundo Kanduang sebagai duta masyarakat Minang di Yogyakarta. Informasi ini peneliti dapatkan dari narasumber perantau Minang di Yogyakarta. (5). Perhatian yang cukup baik dari Pemerintah Propinsi Sumatera Barat dengan memberikan fasilitas asrama berupa kasur, lemari dan meja belajar secara cuma-cuma bagi seluruh anggota asrama serta menanggung segala beban asrama seperti listrik bulanan, air dan PBB.

Di samping beberapa faktor pendukung di atas, peneliti juga menemukan beberapa faktor yang menjadi kendala dalam pengembangan diri warga asrama, yaitu (1). Konflik personal yang terkadang melebar menjadi konflik antar kelompok atau warga asrama. Meski sangat jarang terjadi namun kondisi ini patut diwaspadai bagi warga asrama agar senantiasa menjaga kondisi yang harmonis dalam bergaul di lingkungan asrama. (2). Ketidaksepahaman antar warga asrama dalam melaksakan suatu kegiatan bersama. Kondisi ini seringkali muncul ketika pelaksanaan suatu kegiatan tidak disetujui oleh sebagian anggota asrama. (3). Sikap kurang senang dan cenderung bernada protes terhadap beberapa kegiatan yang umumnya muncul dari anggota baru asrama. (4). Campur tangan yang terlalu berlebihan dari KP Sumbar sehingga warga seperti didikte untuk melaksanakan suatu kegiatan. Hal ini dapat membatasi ruang gerak dan kreatifitas warga asrama. (5). Ketidakmampuan warga asrama melebur dengan budaya setempat salah satunya terkendala penguasaan Bahasa daerah setempat (bahasa Jawa). Hal ini terjadi karena warga lebih banyak menghabiskan waktu bersama warga asrama lainnya saja sehingga bahasa sehari-hari warga ketika berada di asrama menggunakan bahasa Minang dan Bahasa Indonesia digunakan saat berada di kampus.

\section{Karakteristik Mahasiswa Yang Mengaktualisasikan Diri}

Beberapa karakteristik dari mahasiswa di Asrama Putri Bundo Kanduang dalam rangka mengaktualisasikan diri dapat dijelaskan sebagai berikut.

Pertama, mengamati realitas secara efisien. Warga asrama melihat hidup di tanah rantau secara jernih dan apa adanya. Mereka bersikap obyektif dengan lingkungan yang baru. Sikap ini ditunjukkan dalam proses aktualisasi diri selama berada di Asrama Putri Bundo Kanduang. Realitas kehidupan di Yogyakarta yang sangat berbeda dengan 
lingkungan rumah di daerah asal memberi tantangan dan semangat tersendiri bagi warga asrama.

Kedua, penerimaan umum atas kodrat, orang-orang lain dan diri sendiri. Warga asrama secara sadar menerima kondisi kehidupan yang sekarang dijalani di asrama dan di Yogyakarta. Dengan kelebihan dan kekurangan pribadi tidak menimbulkan permasalahan dalam proses aktualisasi diri mereka. Begitu juga dengan penerimaan terhadap rekan satu asrama, rekan satu perkuliahan dan lingkungan. Warga asrama menjalani peran apa adanya, menerima kondisi rekan satu asrama dengan segala kelebihan dan kekurangan pula.

Ketiga, spontanitas, kesederhanaan dan kewajaran. Warga asrama berusaha menempatkan dirinya dalam posisi yang sewajar dan senyaman mungkin. Perilaku yang timbul bersifat spontanitas tanpa berpura-pura sehingga ketika muncul suatu konflik pun mereka mengungkapkan dengan jujur dan apa adanya. Kedekatan emosional dengan seluruh warga asrama membuat setiap warga merasa nyaman dan menempatkan rekan-rekannya sebagai keluarga baru.

Keempat, fokus pada masalah-masalah di luar diri mereka. Warga asrama melibatkan diri dalam penyelesaian permasalahan yang ada disekitar mereka terutama yang dipandang penting dan berguna bagi pengembangan diri. Hal ini dapat dilihat pada partisipasi aktif warga asrama dalam setiap kegiatan yang diadakan asrama. Meskipun menuntut adanya kedisiplinan, tanggung jawab, kerja keras, bahkan punishment bagi pelanggarnya mereka tidak menjadikan itu sebagai halangan dan justru menjadi kepuasan tersendiri jika dapat terlaksana dengan baik.
Kelima, kebutuhan akan privasi dan dependensi. Warga asrama kurang memiliki ranah privasi sendiri baik dari segi fisik maupun non fisik sebagai konsekuensi dari hidup bersama. Oleh karena itu dalam menyelesaikan permasalahan dan pengambilan keputusan mereka sering bergantung pada orang lain bahkan pada warga asrama.

Keenam, berfungsi secara otonom. Warga asrama mengaktualisasikan dirinya bersumber dari potensi internal. Kemampuan dan bakat pribadi menjadi andalan warga asrama dalam berperilaku sehari-hari. Sikap ini juga berarti kemandirian hidup dimana warga asrama tidak menggantungkan dirinya pada kemampuan orang lain namun berasal dari diri pribadi.

Ketujuh, apresiasi yang senantiasa segar. Warga asrama sangat menghargai dan mengapresiasi setiap pencapaian positif dan pengalaman baik pengalaman diri maupun orang lain. Apresiasi terhadap pengalaman diri yang segar memberi energi baru untuk terus mengembangkan diri. Sementara apresiasi terhadap orang lain merupakan wujud penghargaan tulus mereka terhadap pencapaian rekan asrama.

Kedelapan, pengalaman-pengalaman mistik atau “puncak”. Pengalaman-pengalaman ini mencakup pengalaman spiritual yang sangat mendalam. Meskipun merupakan salah satu karakteristik dari aktualisasi diri namun dari penuturan warga asrama belum merasakan adanya pengalaman seperti ini. Pengalaman yang mereka ungkapkan umumnya bersifat eksplisit.

Kesembilan, minat sosial. Warga asrama memiliki jiwa sosial yang cukup tinggi misalnya dalam memberi perhatian terhadap orang lain terutama terhadap warga asrama lainnya. Perhatian yang diberikan dalam 
bentuk saling membantu dalam beberapa kegiatan baik yang bersifat personal maupun kegiatan yang sudah diagendakan.

Kesepuluh, hubungan antar pribadi. Sejalan dengan minat sosial pada poin sebelumnya, sikap memberi perhatian terhadap sesama anggota asrama pada gilirannya akan meningkatkan hubungan antar individu. Hubungan baik yang terus menerus terjalin akan melahirkan perasaan nyaman dan kasih sayang sehingga membentuk persahabatan yang erat. Dalam pengamatan peneliti warga asrama saling memberikan kasih sayang satu sama lain.

Kesebelas, struktur watak demokratis. Watak demokratis diartikan penerimaan terhadap siapapun tanpa memandang kelas sosial, tingkat pendidikan, penampilan, dan ciri lainnya. Warga asrama yang hetrogen baik dari sisi asal daerah, angkatan, dan usia tidak menjadi halangan bagi pergaulan mereka. Informan menyatakan bahwa sekat-sekat tersebut cenderung dihilangkan agar setiap warga merasa nyaman berada di asrama.

Keduabelas, penentuan sarana dan tujuan antara baik dan buruk. Warga asrama sangat arif dalam menentukan apa yang menjadi sarana dan tujuan terutama dengan keputusan merantau ke Yogyakarta. Tujuan yang utama adalah melanjutkan pendidikan sementara asrama merupakan salah satu sarana dalam mewujudkan tujuan tersebut. Oleh karena itu pencapaian tujuan lebih penting dan didahulukan.

Ketigabelas, perasaan humor tidak menimbulkan permusuhan. Warga asrama memiliki selera humor yang cukup bagus namun mereka menempatkannya pada kondisi yang tepat. Meskipun demikian, dalam beberapa kesempatan informan mengakui terkadang mereka terkesan berlebihan dalam mengekspresikan selera humor ini sehingga tidak jarang menimbulkan perasaan tidak senang dari lawan bicaranya.

Dari penelitian yang telah dilakukan dan berdasar pada analisis menggunakan teori dan faktor-faktor di atas maka peneliti mendeskripsikan beberapa point penting yang menjadi hasil dalam proses aktualisasi diri warga asrama, yaitu

Pertama, para mahasiswa sudah dapat memenuhi sebagian besar kebutuhankebutuhan dasar serta motivasi untuk mencapai proses aktualisasi diri, sehingga pada gilirannya proses aktualisasi diri dapat berjalan cukup optimal yang ditunjukkan melalui kegiatankegiatan yang sudah dijelaskan pada bagian sebelumnya.

Kedua, proses aktualisasi diri dapat berjalan baik karena para mahasiswa melaksanakannya dengan rasa senang, tanpa ada beban dan penuh dengan tanggung jawab. Hal ini menjadi perhatian penting karena senada dengan yang dikemukakan Maslow bahwa kondisi psikologis seseorang berpengaruh pada perilaku yang ditimbulkan. Jika seseorang melaksanakan suatu hal dengan perasaan terpaksa atau tertekan maka hasilnya juga tidak akan optimal.

Ketiga, meskipun dalam prakteknya terjadi beberapa kendala dan permasalahan, namun hal tersebut tidak berpengaruh signifikan terhadap proses aktualisasi diri mahasiswa. Peneliti mengamati bahwa para mahasiswa cenderung bersikap lebih arif dan bijaksana dalam menyelesaikannya. Setiap kendala yang muncul segera diselesaikan baik secara personal maupun dalam forum musyawarah bersama sehingga tidak ada permasalahan yang dibiarkan berlarut-larut. 
Irwan, Muhamad Supraja, Ahmad Zubaidi -- Dinamika Aktualisasi Diri Pemuda Rantau Dan Implikasinya Terhadap Ketahanan Pribadi (Studi Pada Mahasiswa Rantau Asal Sumatra Barat Di Asrama Putri Bundo Kanduang Daerah Istimewa Yogyakarta)

\section{Implikasinya Terhadap Ketahanan} Pribadi

Proses aktualisasi diri yang telah dilakukan warga Asrama Putri Bundo Kanduang telah berimplikasi terhadap ketahanan pribadi mereka. Implikasi ini untuk menjawab pertanyaan penelitian yang kedua. Implikasi aktualisasi diri terhadap ketahanan pribadi dideskripsikan melalui beberapa nilai ketahanan pribadi. Nilainilai tersebut dikemukakan oleh Soedarsono (1997) sebagai berikut: memiliki rasa percaya diri dan berpegang pada prinsip, mandiri dan bebas dari rasa ketergantungan, tetapi mendambakan kebersamaan, memiliki jiwa dinamis, kreatif, dan pantang menyerah, serta mengedepankan kepentingan umum di atas kepentingan pribadi.

Pertama, percaya diri dan memegang prinsip. Kepercayaan diri merupakan suatu keyakinan terhadap kemampuan diri pribadi untuk berperilaku ataupun dalam memperoleh suatu hasil sesuai yang diharapkan. Kepercayaan diri ditujukan pada suatu keyakinan bahwa seseorang dapat melakukan sesuatu sesuai dengan harapannya (Bandura, 1977). Kepercayaan diri merupakan suatu sikap positif individu yang yakin akan kemampuan dirinya untuk mengembangkan penilaian positif, baik terhadap diri sendiri maupun terhadap lingkungan atau situasi yang dihadapinya (Fatimah, 2006).

Kepercayaan diri tersebut ditunjukkan oleh pemuda di Asrama Bunda Kanduang dalam beberapa karakteristik pribadi, yaitu (1). Pemuda yang memiliki kepercayaan diri akan berjuang secara aktif mencapai suatu tujuan. Warga asrama telah berjuang dan berperan aktif dalam melaksanakan kegiatan-kegiatan yang diadakan asrama Bundo Kanduang. Hal ini dapat dilihat dari berbagai kegiatan baik harian, mingguan bulanan, bahkan tahunan yang melibatkan seluruh warga asrama. (2). Setiap keputusan yang keluar berdasar pada analisis kritis ilmu pengetahuan. Hal ini sering diaplikasikan oleh warga asrama terutama saat rapat bulanan berkala atau jenis pertemuan lain dimana mereka selalu menganalisa secara kritis setiap ide dan gagasan yang diutarakan di dalam forum. (3). Mampu menganalisis secara mandiri. Para warga asrama tidak pernah bergantung kepada rekannya dalam memecahkan suatu permasalahan. Setiap analisis kritis muncul dari diri sendiri dan dilemparkan ke dalam forum untuk dibahas secara bersama, terlepas apakah ide tersebut akan diterima atau justru ditolak pada akhirnya. (4). Mengontrol pikiran dalam hubungan yang tepat. Sikap ini dapat dipahami sebagai upaya menjaga kestabilan emosi terutama ketika berhubungan dengan orang lain. Sikap ini umumnya dapat diaplikasikan oleh para warga asrama misalnya dalam menyelesaikan suatu permasalahan pribadi atau dengan pihak lain. Sebelum suatu masalah atau konflik semakin meruncing, pihak yang bersangkutan selalu diminta untuk menyelesaikannya. Sikap kepercayaan diri sejalan dengan sikap memegang prinsip. Pemuda yang percaya diri umumnya memiliki prinsip hidup yang kuat dimana ia menetapkan koridor-koridor ataupun batasan tertentu dalam hidupnya. Ketika berada dalam lingkungan asrama, umumnya warga memberikan toleransi bagi dirinya sendiri serta warga asrama lain dalam kaitannya dengan persoalan prinsip. Artinya tidak serta merta para warga saklek dengan prinsip hidupnya. Lingkungan asrama yang menuntut segala sesuatu untuk dilakukan bersama menuntut mereka agar lebih fleksibel dan dinamis dengan kondisi seperti itu. Jika prinsip pribadi tetap dipertahankan maka 
ada kecendrungan mahasiswa dicap sebagai pribadi yang egois dan intoleran.

Kedua, mandiri atau kemandirian. Menurut Maslow (1994) mandiri atau kemandirian adalah suatu bentuk aktualisasi diri yang lebih merasa tidak tergantung kepada orang. Sebagai anak perantauan yang jauh dari orang tua sangat menuntut warga asrama untuk hidup mandiri di segala hal. Dapat dikatakan bahwa dampak terbaik dari proses merantau adalah membangun kemandirian. Sikap mandiri dapat tercermin misalnya dalam mengatur keuangan, menyelesaikan masalah baik pribadi maupun kelompok serta beberapa aspek lainnya. Dalam Jurnal Teknosains (Baqi,dkk, 2000) menyatakan “..karena keterbatasan sumberdaya manusia, yang sebagian besar yang pergi merantau, hampir tanpa persiapan, namun menyisakan sejumlah harapan dan optimis, yakni semangat kemandirian”.

Lebih khusus dalam aspek ekonomi, wujud nyata sikap mandiri yaitu pemuda harus berinovasi membangun usaha sendiri yang sekarang akrab dengan istilah wirausaha atau kewirausahaan. Jauh sebelum semangat wirausaha yang sekarang berkembang di Indonesia, masyarakat Minangkabau sejak dahulu telah menanamkan sikap ini sedari kecil terhadap pemuda di Minangkabau terutama kaum laki-laki. Didikan yang ditanamkan orang tua terhadap anaknya adalah bagaimana strategi hidup sendiri, mencari uang sendiri tanpa harus bergantung kepada orang tua dan pada akhirnya dididik untuk merantau. Agar mampu bertahan di perantauan maka 'wejangan-wejangan' yang diterima sejak kecil menjadi bekal pemuda dalam menjalani hidupnya di tanah rantau.

Kemandirian ekonomi dalam jiwa pemuda rantau harus dikembangkan tidak hanya bagi dirinya sendiri tetapi yang terpenting bagaimana ia dapat menularkan semangat kemandirian dalam skala yang lebih luas seperti lingkungan sosial masyarakat hingga kemandirian bangsa. Kemandirian ekonomi dapat dimulai dengan aktif menggunakan produk dalam negeri, berusaha sebisa mungkin untuk tidak bergantung pada produk impor. Generasi muda seyogyanya menjadi pelopor untuk mewujudkan hal ini dan jangan sampai justru pemuda menunjukkan prilaku konsumtif dan bergantung pada produk impor.

Ketiga, jiwa dinamis, kreatif, dan pantang menyerah. Sikap dinamis terdapat pada penggalan awal definisi ketahanan nasional yaitu "kondisi dinamis bangsa Indonesia". Sikap dinamis sangat diperlukan bagi pemuda karena sikap ini mesyaratkan semangat cepat bertindak dalam menyelesaikan suatu permasalahan serta dapat menyesuaikan diri dengan berbagai kondisi. Sikap dinamis setali tiga uang dengan sikap kreatif dan pantang menyerah. Kreatif berarti mampu melahirkan inovasi baru dan tidak terkungkung pada satu sistem yang baku. Sedangkan sikap pantang menyerah bermakna semangat yang tidak pernah pudar meskipun mengalami suatu kegagalan dalam mencapai suatu target.

Dari wawancara dan pengamatan yang peneliti lakukan para warga asrama bersikap sangat dinamis dimana mereka mampu menyelesaikan berbagai permasalahan baik individu maupun permasalahan kelompok dengan baik sehingga tidak mengganggu proses aktualisasi diri. Hidup bersama 22 orang selama satu tahun menyebabkan para warga asrama terbiasa dengan karakter teman yang beranekaragam. Kemudian para warga cukup mampu menyesuaikan diri dengan keadaan dan lingkungan. Sikap kreatif terlihat 
pada penyusunan program kerja tahunan yang tidak selalu sama dengan tahun sebelumnya. Artinya disetiap kepengurusan asrama selalu memunculkan satu bentuk kegiatan terbaru. Warga asrama dituntut untuk memberikan evaluasi dan penilaian personal terhadap program kerja yang telah dilakukan sebelumnya. Selanjutnya mereka diminta untuk menyumbangkan ide dan gagasan tentang program-program kerja baru yang kiranya bermanfaat dan dapat diwujudkan oleh kepengurusan selanjutnya.

Dalambidang kesenian, Peneliti mengamati sendiri saat mereka berusaha dengan semangat pantang menyerah dalam menguasai suatu tari daerah. Misalnya dalam penguasaan tari Piring yang merupakan salah satu tarian yang paling sulit karena harus menari sambil membawa piring kaca tanpa pengaman apapun. Warga asrama sangat antusias dalam belajar tari ini meskipun seringkali properti piring ini jatuh dan pecah saat digunakan. Latihan demi latihan terus diikuti mulai dari teknik memegang piring hingga teknik gerakan tari itu sendiri. Semangat belajar tari merupakan satu contoh konkrit dari semangat pantang menyerah warga Asrama Putri Bundo Kanduang.

Keempat, mengedepankan kepentingan umum di atas kepentingan pribadi. Sikap ini sejatinya berlaku mutlak bagi siapapun terutama bagi generasi muda. Sikap mengutamakan kepentingan umum di atas kepentingan pribadi sejalan dengan amanat Pancasila Sila Kelima dimana kepentingan bersama harus senantiasa dijunjung tinggi dalam kehidupan sebagai makhluk sosial. Para pemuda yang tinggal di asrama secara tidak langsung sudah dididik untuk bersikap seperti ini. Dalam lingkungan asrama setiap mahasiswa harus mendahulukan kepentingan bersama dalam hal ini kepentingan asrama ketimbang persoalan yang bersifat pribadi. Segala bentuk kegiatan asrama yang sudah dijadwalkan harus terlaksana dan setiap anggota harus mengenyampingkan urusan pribadinya kecuali karena alasan yang rasional seperti yang berhubungan dengan akademik atau kesehatan.

Dalam kegiatan harian asrama setiap warga memberikan perhatian dan partisipasi yang lebih agar setiap kegiatan dapat terlaksana sebagaimana mestinya meskipun bukan bagian dari divisinya. Misalnya dalam melaksanakan bakti sosial ke panti asuhan yang sejatinya merupakan program kerja divisi Kerohanian, namun semua anggota berpartisipasi aktif dalam kegiatan tersebut. Mereka memberikan perhatian yang antusias meskipun setiap warga juga memiliki urusan masing-masing yang harus dilaksanakan tetapi kegiatan bersama warga asrama selalu menjadi prioritas.

Aktualisasi Diri menjadi penting bagi pemuda untuk mewujudkan ketahanan pribadi yang kuat dan tangguh. Proses aktualisasi diri yang dilakukan warga Asrama Putri Bundo Kanduang menunjukkan hasil yang cukup menggembirakan. Hal ini disebabkan karena telah terpenuhinya kebutuhan mendasar dalam kehidupan sehari-hari. Pada gilirannya proses aktualisasi diri dilakukan salah satunya melalui serangkaian kegiatan yang sudah diatur dalam kepengurusan di asrama. Diharapkan nilainilai tersebut sudah tertanam dan tercermin dalam kehidupan warga asrama sehari-hari baik di lingkungan asrama, kampus maupun lingkungan lainnya.

Urgensi ketahanan pribadi bagi pemuda karena ketahanan pribadi merupakan fondasi awal perwujudan ketahanan nasional. Sementara pemuda merupakan 'bonus demografi' bangsa yang sangat potensial untuk terus diberdayakan di segala aspek 
kehidupan bernegara. Populasi pemuda Indonesia yang jumlahnya sangat besar sejatinya diimbangi dengan kualitas individu yang mumpuni. Jika pertumbuhan kuantitas pemuda tidak diimbangi dengan peningkatan kualitas pemudanya maka justru eksistensi pemuda justru menjadi beban bagi negara. Dalam Undang Undang Nomor 40 Tahun 2009 Tentang Kepemudaan juga diatur secara rinci mengenai peran, tanggung jawab dan hak pemuda yakni pada pasal 16 yang berbunyi: "Pemuda berperan aktif sebagai kekuatan moral, kontrol sosial, dan agen perubahan dalam segala aspek pembangunan nasional.

\section{SIMPULAN}

Dari penjelasan tersebut di atas dapat ditarik simpulan sebagai berikut.

Pertama, dinamika aktualisasi diri warga Asrama Putri Bundo Kanduang diawali dengan pemenuhan kebutuhan dan motivasi hidup sebagai upaya untuk mewujudkan proses aktualisasi diri yang optimal. Pada prakteknya proses aktualisasi diri dapat terlaksana dengan baik dalam bentuk kegiatankegiatan rutin asrama karena mayoritas kebutuhan-kebutuhan tersebut telah terpenuhi. Meskipun terdapat beberapa kendala dalam pengembangan diri mahasiswa, namun hal tersebut tidak berpengaruh secara signifikan karena kendala-kendala tersebut bersifat temporer dan dapat segera diatasi oleh warga asrama. Selain itu beberapa faktor pendukung baik internal dan eksternal dapat memperkuat proses aktualisasi diri warga asrama.

Kedua, proses aktualisasi diri yang sudah berjalan dengan baik tersebut berimplikasi pada penguatan ketahanan pribadi pemuda yang cukup baik dan tangguh pula. Implikasi tersebut dapat dilihat dari perwujudan nilai-nilai ketahanan pribadi yaitu: percaya diri dan memegang prinsip; mandiri; jiwa kreatif, dinamis, dan pantang menyerah; serta mengedepankan kepentingan umum diatas kepentingan pribadi.

\section{DAFTAR PUSTAKA}

Bandura, A, 1977, Social Learning Theory, New York, Prentice-Hall Inc.

Baqi, dkk, 2000, Strategi Usaha Rumah Tangga Pedagang Kakilima Minangkabau di Kawasan Malioboro Kotamadya Yogyakarta,

Fatimah, E, 2006, Psikologi Perkembangan: Perkembangan Peserta Didik, Bandung, Balai Setia.

Goble, F.G, 1987, Mazhab Ketiga: Psikologi Humanistik Abraham Maslow, Yogyakarta, Kanisius

Kaelan, H, 2012, Metode Penelitian Kualitatif Interdisipliner, Yogyakarta, Paradigma

Maslow, A.H, 1994, Motivasi dan Kepribadian Vol.2, Seri Manajemen no.104, Jakarta, Pustaka Binama Pressindo

Soedarsono, Soemarno, 1997, Ketahanan Pribadi dan Ketahanan Keluarga Sebagai Tumpuan Ketahanan Nasional, Jakarta, Intermasa

Sugiyono, 2013, Metode Penelitian Kuantitatif, Kualitatif dan R\&D, Bandung, Alfabeta Winstedt, R.O, 1960, Kamus Bahasa Melayu, Singapura, Marican and Sons

Zohar, D dan Marshall, I, 2000, SQ: Memanfaatkan Kecerdasan Spiritual dalam Berfikir Integralistik dan Holistik untuk Memaknai Kehidupan, Bandung, Mizan

\section{Peraturan Perundangan}

Undang-Undang Nomor 40 Tahun 2009 Tentang Kepemudaan 